\title{
Association of the Kinesin Superfamily Motor Protein KIF1B $\alpha$ with Postsynaptic Density-95 (PSD-95), Synapse-Associated Protein-97, and Synaptic Scaffolding Molecule PSD-95/Discs Large/Zona Occludens-1 Proteins
}

\author{
Hyejung Mok, ${ }^{*}$ Hyewon Shin, ${ }^{*}$ Seho Kim, Jae-Ran Lee, Jiyoung Yoon, and Eunjoon Kim \\ Department of Biological Sciences, Korea Advanced Institute of Science and Technology, Daejeon 305-701, Korea
}

Mutation in KIF1B, a kinesin superfamily motor protein, causes a peripheral neuropathy known as Charcot-Marie-Tooth disease type 2A (CMT2A). Little is known, however, about how a defective KIF1B gene leads to CMT2A. Here we report that $\mathrm{KIF} 1 \mathrm{~B} \alpha$, one of the two splice variants of KIF1B, directly interacts through its C-terminal postsynaptic density-95 (PSD-95)/ discs large/zona occludens (PDZ) domain-binding motif with PDZ proteins including PSD-95/synapse-associated protein-90 (SAP90), SAP97, and synaptic scaffolding molecule (SSCAM)-90 (SAP90). KIF1B $\alpha$ selectively interacts with PSD-95, SAP97, and S-SCAM in yeast two-hybrid, pull-down, and in

The postsynaptic density (PSD)-95/synapse-associated protein-90 (SAP90) family of proteins and synaptic scaffolding molecule (S-SCAM) are postsynaptic density-95 (PSD-95)/discs large/zona occludens (PDZ) domain-containing proteins that play an important role in the assembly of the synaptic multiprotein complex (Garner et al., 2000; Kennedy, 2000; Scannevin and Huganir, 2000; Sheng and Sala, 2001; Tomita et al., 2001). In contrast to their suggested roles at synaptic sites, a number of biochemical and electron microscopic (EM) studies have shown that the four known members of the PSD-95 family exhibit a diverse subcellular distribution in dendrites and axons of neurons (Hunt et al., 1996; Koulen et al., 1998a,b; Sans et al., 2000, 2001; Valtschanoff et al., 2000; Aoki et al., 2001; Valtschanoff and Weinberg, 2001). In addition, a significant fraction of S-SCAM, a multi-PDZ protein known to interact with membrane proteins including the Kv1.4 potassium channel, the NMDA receptor $2 \mathrm{~B}$ (NR2B) subunit of NMDA receptors, and neuroligin, is recovered in nonsynaptosomal fractions (Hirao et al., 1998). These results strongly suggest that members of the PSD-95 family (termed PSD-95 relatives hereafter) and S-SCAM have novel functions at nonsynaptic sites.

The kinesin superfamily (KIF) motors mediate microtubuledependent transport of a variety of organelles and vesicles (Goldstein and Yang, 2000; Miki et al., 2001). KIF1B (now called

\footnotetext{
Received Jan. 8, 2002; revised April 10, 2002; accepted April 26, 2002.

This work was supported by grants from the Korean Ministry of Science and Technology, the Korea Science and Engineering Foundation, and the Korea Research Foundation. We thank Dr. Michel Streuli for the expression construct of liprin- $\alpha 1$.

*H.M. and H.S. contributed equally to this work.

Correspondence should be addressed to Eunjoon Kim, Department of Biological Sciences, Korea Advanced Institute of Science and Technology, Daejeon 305-701, Korea. E-mail: kime@mail.kaist.ac.kr.

Copyright (C) 2002 Society for Neuroscience $\quad 0270-6474 / 02 / 225253-06 \$ 15.00 / 0$
}

vivo coimmunoprecipitation experiments. $\mathrm{KIF} 1 \mathrm{~B} \alpha$, SAP97, and S-SCAM are widely distributed to both dendrites and axons of cultured neurons and are enriched in the small membrane fraction of the brain. In the flotation assay, KIF1B $\alpha$ cofractionates and coimmunoprecipitates with PSD-95, SAP97, and S-SCAM. These results suggest that the PSD-95 family proteins and S-SCAM have a novel function as $\mathrm{KIF} 1 \mathrm{~B} \alpha$ receptors, linking $\mathrm{KIF} 1 \mathrm{~B} \alpha$ to its specific cargos, and are involved in peripheral neuropathies.

Key words: KIF1B; PSD-95; SAP97; S-SCAM; PDZ; motor; kinesin; transport; Charcot-Marie-Tooth; neuropathy

$\mathrm{KIF} 1 \mathrm{~B} \alpha$ ), a member of the UNC-104/KIF1 family of kinesin motors (for review, see Bloom, 2001), was originally reported as a motor transporting mitochondria (Nangaku et al., 1994). Recently, a longer splice variant of KIF1B (KIF1B $\beta$ ) (Conforti et al., 1999; Gong et al., 1999; Zhao et al., 2001) has been shown to associate with synaptic vesicles containing synaptophysin, synaptotagmin, and SV2 (Zhao et al., 2001). Importantly, genetic targeting of the KIF1B gene causes a substantial decrease in the survival of neurons and perinatal death in $k i f 1 b-/-$ mice as well as progressive muscle weakness in heterozygote mice (Zhao et al., 2001). In addition, a loss-of-function point mutation in the motor domain of KIF1B was detected in human patients with Charcot-Marie-Tooth disease type 2A (CMT2A) (Zhao et al., 2001), an autosomal dominant subtype in CMT disease, the most common form of inherited peripheral neuropathies, which is characterized by clinical symptoms including muscular weakness and atrophy. Although the association of KIF1B with neuronal survival and peripheral neuropathies is evident, little is known about how a defective KIF1B gene leads to the severe phenotypes.

We noticed that the $\mathrm{C}$ terminus of $\mathrm{KIF} 1 \mathrm{~B} \alpha$ (RETTV) contains a potential class I PDZ domain-binding motif, S/T-X-V (S/T, Ser or Thr; X, any amino acids; V, hydrophobic amino acids) (Sheng and Sala, 2001). Our yeast two-hybrid screen of a rat brain library using the $\mathrm{KIF} 1 \mathrm{~B} \alpha \mathrm{C}$ terminus as bait pulled out various PDZ proteins, including members of the PSD-95 family and S-SCAM. Here we report lines of evidence supporting the specific association of $\mathrm{KIF} 1 \mathrm{~B} \alpha$ with PSD-95 relatives and S-SCAM in vitro and in vivo. Our results suggest that PSD-95 relatives and S-SCAM, as $\mathrm{KIF} 1 \mathrm{~B} \alpha$ receptors, are involved in the $\mathrm{KIF} 1 \mathrm{~B} \alpha$-mediated transport of neuronal proteins. 


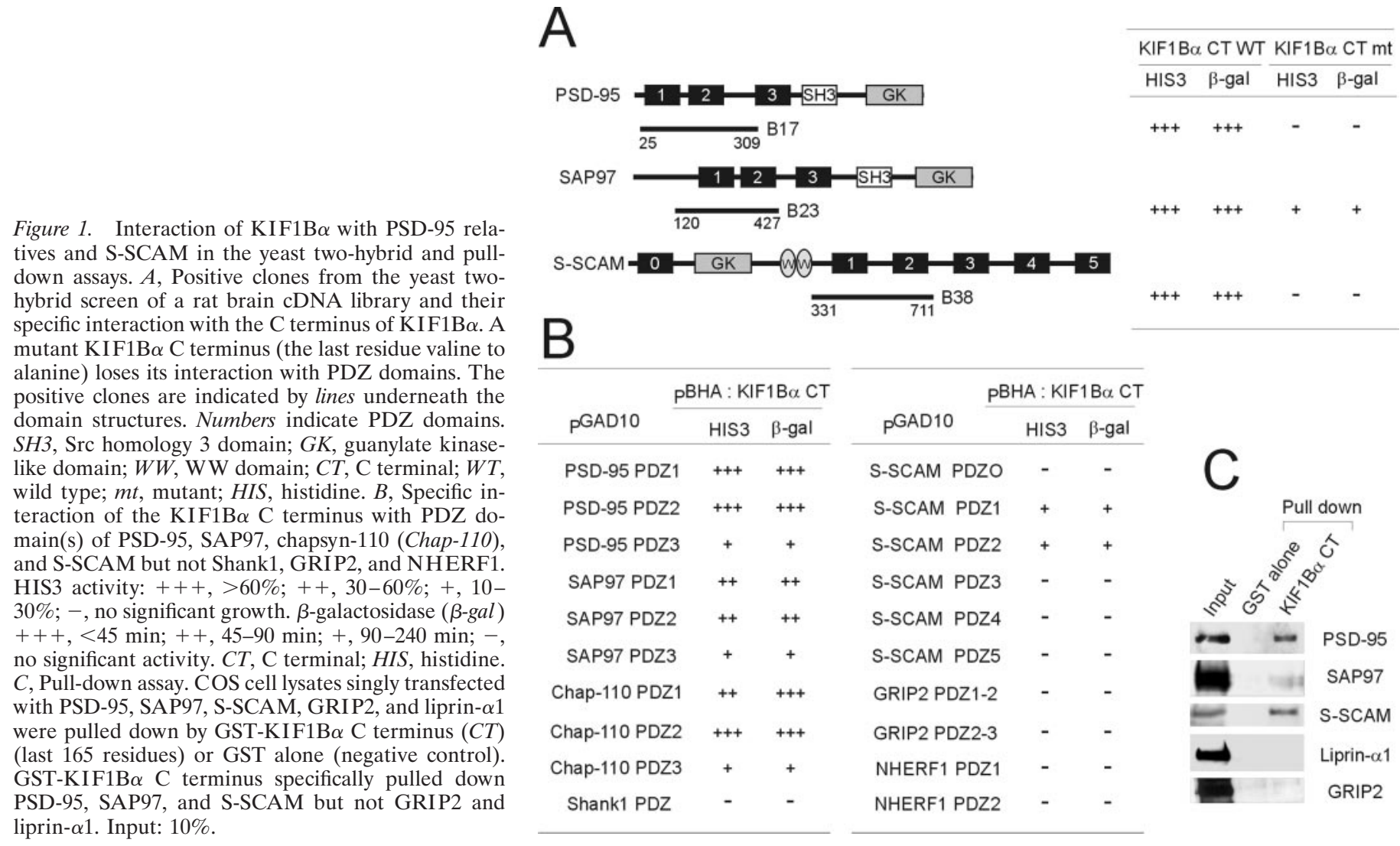

\section{MATERIALS AND METHODS}

Yeast two-hybrid analysis. The two-hybrid assay was performed as described previously (Kim et al., 1995). The last 7 aa residues (amino acids 1144-1150; AGRETTV) of KIF1B $\alpha$ in pBHA bait vector were used in the screen. For the yeast two-hybrid assay against various PDZ domains, wild-type and mutant (the last amino acid V to A) KIF1B $\alpha$ (amino acids 1083-1150) in pBHA were used. The PDZ domains in pGAD10 are as follows: PDZ1 (amino acids 203-327), PDZ2 (304-425), and PDZ3 (454-553) of SAP97; PDZ0 (16-103), PDZ1 (424-505), PDZ2 (607683), PDZ3 (777-863), PDZ4 (919-1023), and PDZ5 (1139-1224) of S-SCAM; Shank1 PDZ (585-691); PDZ1-2 (51-245) and PDZ2-3 (148339) of glutamate receptor-interacting protein-2 (GRIP2) and PDZ1 (13-106) and PDZ2 (142-249) of $\mathrm{Na}^{+} / \mathrm{H}^{+}$exchanger regulatory factor-1 (NHERF1). The pGAD10 constructs containing the PDZ domains of PSD-95 have been described previously (Kim et al., 1995).

Antibodies. Anti-peptide KIF1B $\alpha$ antibodies were raised against the following synthetic peptides: DIIDTSMGSLTSSPSSC (amino acids 384400; rabbit 1161) and CQFSAPNLKAGRETTV (amino acids 11361150; guinea pig 1189; $\underline{\mathrm{C}}$, added for coupling). Anti-fusion protein polyclonal antibodies were generated using H6-KIF1B $\alpha$ (amino acids 911-1150; guinea pig 1183), H6-S-SCAM (amino acids 341-711; rabbit 1146), and glutathione $S$-transferase (GST)-Homer-1a (amino acids 1-186; rabbit 1133) as immunogens, respectively. The following antibodies have been described previously: PSD-95 (HM319) (Kim et al., 1995), PSD-95 (SM55) (Choi et al., 2002), SAP97 (B9591) (Kim et al., 1996), liprin- $\alpha$ (1127) (H. Shin and E. Kim, unpublished observations), and GRIP (C8399 and 1756) (Wyszynski et al., 1998). The following antibodies were obtained from commercial sources: NR1 (PharMingen, San Diego, CA), MAP2 (Sigma, St. Louis, MO), PSD-95 (K28/86; Upstate Biotechnology, Lake Placid, NY), and synaptotagmin (Sigma).

Pull-down assay. COS cell lysates precipitated with GST-KIF1B $\alpha$ (amino acids 987-1150) were analyzed by PSD-95 (HM319; 1:1000), S-SCAM (1146; 1:500), SAP97 (B9591; 1:500), liprin- $\alpha(1127 ; 1 \mu \mathrm{g} / \mathrm{ml})$, and GRIP (1756; 1:500) antibodies. For pCDNA3 S-SCAM, amino acids 1-1277 of S-SCAM $\alpha$ were amplified from marathon-ready cDNA (Clontech, Palo Alto, CA) and subcloned into pCDNA3. For GW1 GRIP2, amino acids $29-1043$ of GRIP2 were subcloned into GW1 containing a myc tag. Other expression constructs [PSD-95 (Kim et al., 1995) and SAP97 (Kim and Sheng, 1996)] have been described previously.
Neuronal staining. Cultured hippocampal neurons were fixed with $4 \%$ paraformaldehyde, permeabilized by methanol, and incubated with primary antibodies $[\mathrm{KIF} 1 \mathrm{~B} \alpha(1189 ; 3 \mu \mathrm{g} / \mathrm{ml})$, PSD-95 (SM55; $3 \mu \mathrm{g} / \mathrm{ml})$, SAP97 (B9591; $3 \mu \mathrm{g} / \mathrm{ml})$, S-SCAM $(3 \mu \mathrm{g} / \mathrm{ml})$, and MAP2 (1:200)], followed by Cy3- or FITC-conjugated secondary antibodies. Neuronal images were captured by confocal laser scanning microscopy (LSM510; Zeiss, Oberkochen, Germany).

Subcellular fractionation and immunoprecipitation. Subcellular fractionation of rat brain proteins was performed as described previously (Wyszynski et al., 1998). For coimmunoprecipitation with the S2 fraction, samples in binding buffer (25 mM HEPES, $120 \mathrm{~mm} \mathrm{KCl}, 1 \mathrm{mg} / \mathrm{ml} \mathrm{BSA}$, $0.1 \%$ Triton $\mathrm{X}-100, \mathrm{pH} 7.4$ ) were incubated with $\mathrm{KIF} 1 \mathrm{~B} \alpha$ antibody $(1183 ; 10 \mu \mathrm{g} / \mathrm{ml})$ or guinea pig $\mathrm{IgG}$, precipitated with protein A-Sepharose, and analyzed with $\mathrm{KIF} 1 \mathrm{~B} \alpha$, the PSD-95 family (K28/86; 1 $\mu \mathrm{g} / \mathrm{ml})$, S-SCAM, and GRIP (C8399; $1 \mu \mathrm{g} / \mathrm{ml})$ antibodies.

Flotation assay and coimmunoprecipitation. Six-week-old rat brains were homogenized in ice-cold homogenization buffer $(0.32 \mathrm{M}$ sucrose, 4 mM HEPES, $\mathrm{pH} 7.3$ ) and centrifuged at $800 \times g$ for $20 \mathrm{~min}$. The supernatant was added to nine volumes of $\mathrm{H}_{2} \mathrm{O}$ to obtain a hypotonic shock that would disrupt synaptosomes, followed by centrifugation at $25,000 \times g$ for $20 \mathrm{~min}$. After additional centrif ugation of the supernatant at $200,000 \times g$ for $1 \mathrm{~h}$, the pellet was resuspended in $2 \mathrm{M}$ sucrose solution in homogenization buffer and loaded at the bottom of a discontinuous sucrose gradient of $0.3,1.0$, and $1.6 \mathrm{M}$. After centrifugation at $350,000 \times$ $g$ for $3 \mathrm{~h}$, fractions were analyzed by immunoblotting with antibodies against KIF1B $\alpha$, PSD-95 (SM55; $1 \mu \mathrm{g} / \mathrm{ml})$, SAP97 (1 $\mu \mathrm{g} / \mathrm{ml})$, S-SCAM $(1 \mu \mathrm{g} / \mathrm{ml})$, NR1 $(1 \mu \mathrm{g} / \mathrm{ml})$, synaptotagmin (1:1000), GRIP (C8399), and Homer-1 (1:1000). Coimmunoprecipitation on the floated fractions was performed as described above. The precipitates were analyzed by immunoblotting with KIF1B $\alpha$, PSD-95 (SM55), SAP97, S-SCAM, synaptotagmin, and GRIP (C8399) antibodies.

\section{RESULTS}

\section{Interaction of KIF1B $\alpha$ with PSD-95, SAP97, and S-} SCAM in the yeast two-hybrid and pull-down assays

To identify binding partners of the $\mathrm{C}$ terminus of $\mathrm{KIF} 1 \mathrm{~B} \alpha$, a rat brain cDNA library was screened using the last seven amino acid residues of $\mathrm{KIF} 1 \mathrm{~B} \alpha$ as bait. A screen of $1 \times 10^{6}$ yeast colonies 


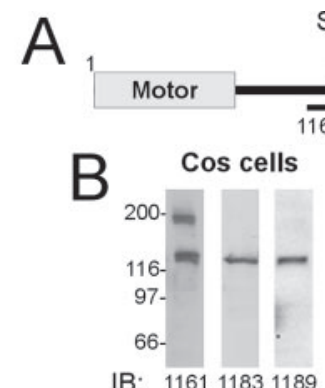

IB: 116111831189
Splice site

$663 / 664$

$\overline{161}$

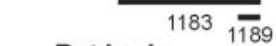

Rat brain

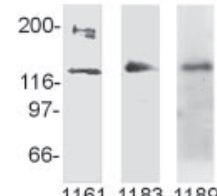

116111831189

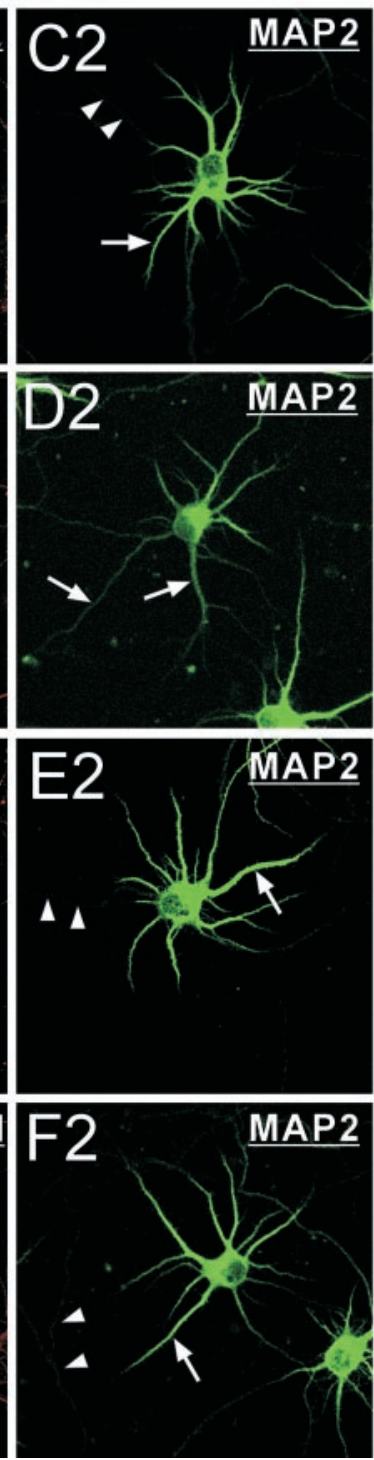
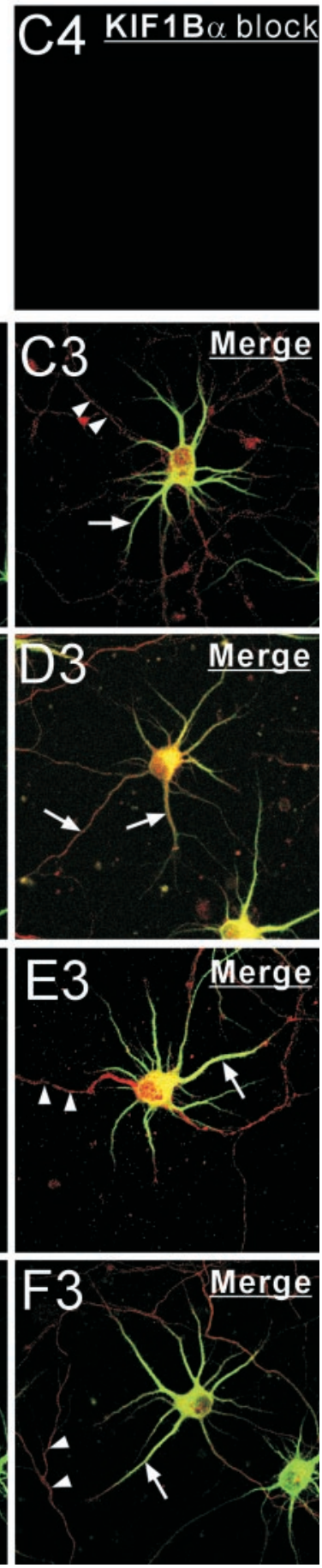

Figure 2. Overlapping distribution of $\mathrm{KIF} 1 \mathrm{~B} \alpha$ with PSD-95, SAP97, and S-SCAM in cultured neurons. $A$, Regions of KIF1B $\alpha$ against which polyclonal antibodies were generated. The two KIF1B splice variants (KIF1B $\alpha$ and $\mathrm{KIF} 1 \mathrm{~B} \beta$ ) begin to diverge at the splice site. $B$, Characterization of the KIF1B antibodies by immunoblot analysis on COS cells and rat brain (S2 fraction) proteins. All three antibodies recognized a $\mathrm{KIF} 1 \mathrm{~B} \alpha$ band (130 $\mathrm{kDa}$ ), and the 1161 antibody recognized an additional band of $200 \mathrm{kDa}(\mathrm{KIF} 1 \mathrm{~B} \beta)$. IB , Immunoblot. $C-F$, Overlapping subcellular distribution of KIF1B $\alpha$ with PSD-95, SAP97, and S-SCAM in cultured hippocampal neurons (at $6 \mathrm{~d}$ in vitro). $\mathrm{KIF} 1 \mathrm{BB} \alpha$ (red, 1189 antibody) is distributed to both MAP2 ( green)-positive dendrites (arrows) and MAP2-negative axons (arrowheads) (C1-C3). The $\mathrm{KIF} 1 \mathrm{~B} \alpha$ staining pattern (1189 antibody) is eliminated by preincubation of the antibody with an excess of free peptide (C4). SAP97 and S-SCAM, similar to KIF1B $\alpha$, are distributed to both MAP2-positive dendrites (arrows) and MAP2-negative axons (arrowheads) $(E, F)$, whereas PSD-95 is distributed primarily to dendrites $(D)$. Scale bar, $30 \mu \mathrm{m}$. pulled out PSD-95, SAP97, and S-SCAM (five, three, and two identical clones, respectively) (Fig. $1 A$ ). Mutation of the last amino acid residue of $\operatorname{KIF} 1 \mathrm{~B} \alpha$, valine to alanine, abolished or significantly reduced its interaction with the positive clones, suggesting that the $\mathrm{C}$ terminus of $\mathrm{KIF} 1 \mathrm{~B} \alpha$ directly interacts with the PDZ domains (Fig. $1 A$ ). In addition, KIF1B $\alpha$ specifically interacted with the PDZ domains of PSD-95, SAP97, chapsyn-110/ PSD-93, and S-SCAM, but not Shank1, GRIP2, and NHERF1 (Fig. $1 B$ ). In the pull-down assay, the GST-KIF1B $\alpha \mathrm{C}$ terminus specifically brought down PSD-95, SAP97, and S-SCAM but not GRIP2 and liprin- $\alpha 1$ (Fig. 1C), consistent with the two-hybrid results. Pull-down efficiency was consistently higher in S-SCAM and PSD-95 relative to SAP97.

\section{Overlapping distribution of KIF1B $\alpha$ with PSD-95,} SAP97, and S-SCAM in cultured neurons

Because subcellular distribution patterns of the PSD-95 family proteins have been extensively characterized at EM levels, we focused on determining the subcellular distribution patterns of $\mathrm{KIF} 1 \mathrm{~B} \alpha$ and S-SCAM and their overlapping localization. To this end, we generated three independent KIF1B antibodies; two against the regions specific for $\mathrm{KIF} 1 \mathrm{~B} \alpha$ (1183 anti-fusion protein 

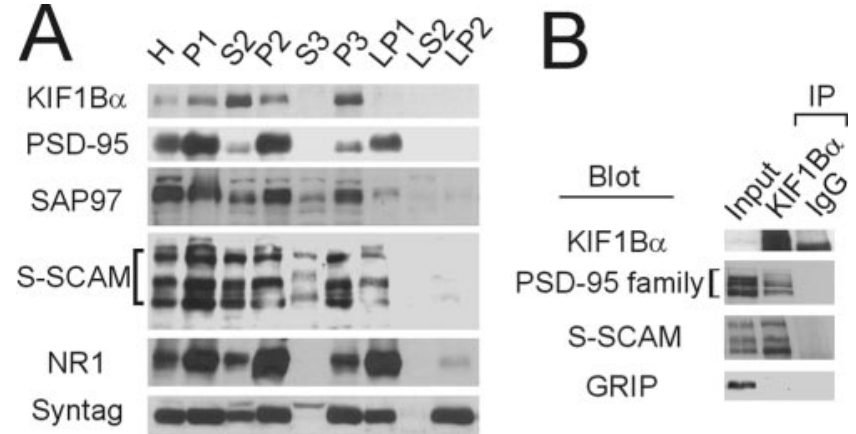

Figure 3. Subcellular fractionation pattern of KIF1B $\alpha$ and its coimmunoprecipitation with PSD-95 relatives and S-SCAM in rat brain. $A$, Subcellular fractionation pattern of $\mathrm{KIF} 1 \mathrm{~B} \alpha$, PSD-95, SAP97, and S-SCAM in rat brain. Subcellular fractions of adult rat brain were immunoblotted for KIF1B $\alpha$, PSD-95, SAP97, S-SCAM, the NR1 subunit of NMDA receptors (NR1), and synaptotagmin (Syntag). H, Total homogenate; $P 1$, nuclei and large debris; $S 2$, supernatant after $\mathrm{P} 2$ precipitation; $P 2$, crude synaptosome; $S 3$, cytosol; $P 3$, small membrane; $L P 1$, synaptosomal membrane; $L S 2$, synaptic cytosol; $L P 2$, synaptic vesicles. LP1, LS2, and LP2 lanes, $10 \mu \mathrm{g}$ of proteins; all other lanes, $20 \mu \mathrm{g}$ of proteins. $B$, Coimmunoprecipitation of KIF1B $\alpha$ with PSD-95 relatives and S-SCAM in rat brain. Lysates of the $\mathrm{S} 2$ fraction were immunoprecipitated $(I P)$ with $\mathrm{KIF} 1 \mathrm{~B} \alpha$ antibody (1183) or guinea pig $\operatorname{IgG}(\operatorname{Ig} G$, control) and immunoblotted for KIF1B $\alpha$, PSD-95 (pan-antibody, K28/86), S-SCAM, and GRIP. Input: $3 \%$.

and 1189 anti-peptide) and one against a region common for KIF1B $\alpha$ and KIF1B $\beta$ (1161 anti-peptide) (Fig. $2 A$ ). The KIF1B antibodies were characterized by immunoblot analysis on COS cells and rat brain samples (Fig. $2 B$ ), because KIF1B $\alpha$ proteins are expressed in various tissues including kidney and brain (Nangaku et al., 1994). All three antibodies recognized a common band of KIF1B $\alpha$ (130 kDa) (Nangaku et al., 1994), and the 1161 antibody recognized an additional band of $\sim 200 \mathrm{kDa}$, the reported size of KIF1B $\beta$ (Zhao et al., 2001).

Immunohistochemistry on cultured hippocampal neurons with the 1189 antibody revealed a wide distribution of $\mathrm{KIF} 1 \mathrm{~B} \alpha$ throughout the neuron, both in MAP2-positive dendrites as well as MAP2-negative axons (Fig. 2C1-C3). Immunostaining with the 1183 antibody revealed an essentially identical pattern (data not shown). The staining pattern by the 1189 or 1183 antibody appears to be specific, because it was eliminated by preincubation of the antibodies with immunogens (Fig. 2C4, an example of 1189 antibody block). These results indicate that $\mathrm{KIF} 1 \mathrm{~B} \alpha$ is distributed to both dendrites and axons in cultured neurons. We also determined the subcellular distribution of PSD-95, SAP97, and S-SCAM (Fig. 2D-F). SAP97 and S-SCAM were distributed to both dendrites and axons, whereas PSD-95 was distributed primarily to dendrites. These results indicate that $\mathrm{KIF} 1 \mathrm{~B} \alpha$ shows an overlapping distribution with PSD-95, SAP97, and S-SCAM in dendrites, but only with SAP97 and S-SCAM, not PSD-95, in axons.

\section{Subcellular fractionation of KIF1B $\alpha$ and its coimmunoprecipitation with PSD-95 relatives and S- SCAM in brain}

To obtain evidence that KIF1B $\alpha$ forms a complex with PSD-95 relatives or S-SCAM in vivo, we first determined their relative abundance in subcellular fractions of adult rat brain (Fig. 3A). $\mathrm{KIF} 1 \mathrm{~B} \alpha$ was more abundant in the $\mathrm{S} 2$ (supernatant after precipitation of the P2 crude synaptosomal fraction) than the P2 fraction. In addition, most of the KIF1B $\alpha$ proteins in the $\mathrm{S} 2$ fraction were partitioned to the small membrane or microsomal (P3) fraction rather than to the cytosolic (S3) fraction, indicating that $\mathrm{KIF} 1 \mathrm{~B} \alpha$ is predominantly localized at nonsynaptic sites and is enriched in the small membrane fraction, consistent with its role as a motor protein transporting organelles and vesicles. PSD-95 was more abundant in the P2 fraction than in the S2 fraction, although most of the PSD-95 proteins in the S2 fraction were partitioned to the P3 fraction. The partition pattern of SAP97 was similar to that of PSD-95, although a relatively large fraction of SAP97 relative to the total was associated with the S2 and P3 fractions. Notably, S-SCAM was almost equally distributed to the $\mathrm{S} 2$ and $\mathrm{P} 2$ fractions, consistent with the previous results (Hirao et al., 1998), and a significant portion of S-SCAM was also detected in the $\mathrm{P} 3$ fraction. These results indicate that, in the descending order of S-SCAM, SAP97, and PSD-95, relatively larger portions of proteins are associated with the small membrane fraction, suggesting that S-SCAM is more likely to be involved in the $\mathrm{KIF} 1 \mathrm{~B} \alpha$-mediated neuronal transport than, for instance, PSD-95. We then determined whether $\mathrm{KIF} 1 \mathrm{~B} \alpha$ forms a complex with PSD-95, SAP97, and S-SCAM in the brain by coimmunoprecipitation experiments on the detergent lysates of the S2 fraction of rat brain (Fig. 3B). KIF1B $\alpha$ antibody coimmunoprecipitated PSD-95 relatives and S-SCAM but not GRIP, consistent with the two-hybrid and pull-down results (Fig. 1).

\section{Cofractionation and biochemical association of KIF1BB $\alpha$ with PSD-95 relatives and S-SCAM in floated light membranes of brain}

If PSD-95 and S-SCAM link KIF1B $\alpha$ to its vesicular cargos, these proteins should be recovered in vesicle-enriched light membrane fractions. First, we separated the light and heavy membranes from rat brain samples (Fig. 4A) (see Materials and Methods for more details). When the light membranes were loaded at the bottom of a discontinuous sucrose gradient in the flotation assay, $\mathrm{KIF} 1 \mathrm{~B} \alpha$ floated with PSD-95, SAP97, S-SCAM, NR1, and synaptotagmin, but not with Homer-1 (Fig. 4B). In addition, the floating was eliminated by adding detergent to the samples before flotation, indicating that the flotation requires intact membranes (Fig. 4B). To determine whether $\mathrm{KIF} 1 \mathrm{~B} \alpha$ specifically associates with PSD-95 relatives and S-SCAM in the floated small membranes, we performed coimmunoprecipitation experiments on the detergent lysates of the floated fractions (fractions 2-5) (Fig. 4C). $\mathrm{KIF} 1 \mathrm{~B} \alpha$ antibody pulled down, in addition to $\mathrm{KIF} 1 \mathrm{~B} \alpha$, proteins including PSD-95, SAP97, and S-SCAM, but not synaptotagmin and GRIP. The lack of coimmunoprecipitation of synaptotagmin, the protein associated with KIF1B $\beta$ (Zhao et al., 2001), confirms a specific association of $\mathrm{KIF} 1 \mathrm{~B} \alpha$ with PSD-95, SAP97, and $\mathrm{S}$-SCAM in the floated small membranes.

\section{DISCUSSION}

In the present study, we demonstrated that $\mathrm{KIF} 1 \mathrm{~B} \alpha$ specifically associates with PSD-95 relatives and S-SCAM among the many PDZ proteins. Our results have three important implications. First, it is becoming increasingly clear that molecular motors associate with their cargos through intermediate "receptor" proteins, examples of which include adaptors, scaffolds, transmembrane proteins, GTPases, and other motors (Klopfenstein et al., 2000). Our results suggest that PSD-95 and S-SCAM, two well known PDZ-containing scaffold proteins, may have unexpected function as KIF1B $\alpha$ receptors. Similarly, LIN-2/LIN-7/LIN-10 PDZ proteins have been shown to link KIF17, a dendrite-specific motor, to NMDA receptors (Setou et al., 2000). The use of PDZ 

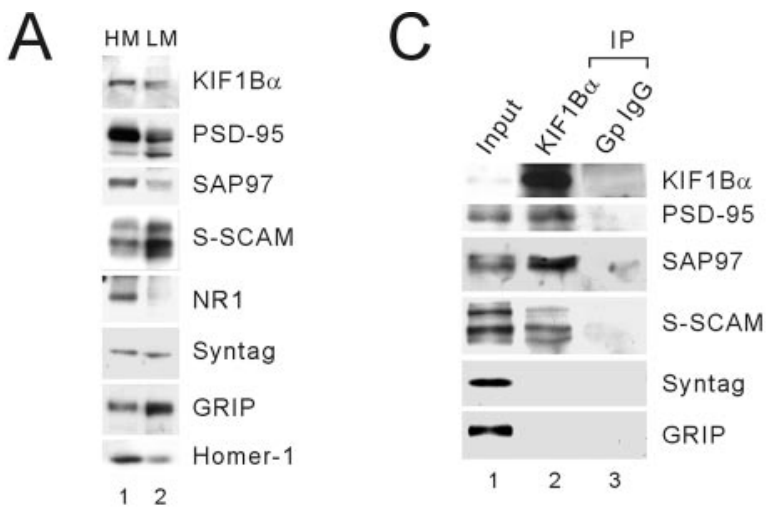

B
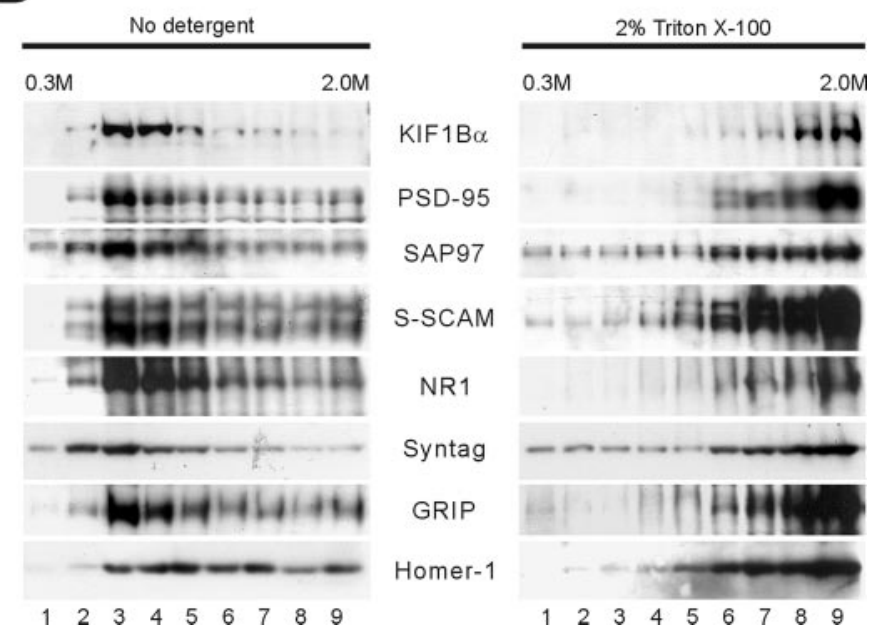

Figure 4. Cofractionation and biochemical association of $\mathrm{KIF} 1 \mathrm{~B} \alpha$ with PSD-95 relatives and S-SCAM in the flotation assay. $A$, Partition of $\mathrm{KIF} 1 \mathrm{~B} \alpha$ and associated proteins into heavy and light membranes. $H M$, Heavy membranes; LM, light membranes; Syntag, synaptotagmin. B, Flotation assay. Samples enriched with light membranes were loaded at the bottom of a discontinuous sucrose gradient and centrifuged for flotation. $\mathrm{KIF} 1 \mathrm{~B} \alpha$ was recovered primarily in light fractions (fractions 2-5) along with PSD-95, SAP97, S-SCAM, NR1, synaptotagmin (Syntag), and GRIP, but not Homer-1. In control experiments, addition of Triton $\mathrm{X}-100$ to samples before flotation eliminated the flotation. $C$, Coimmunoprecipitation of KIF1B $\alpha$ with PSD-95 relatives and S-SCAM in floated membranes. Floated fractions (2-5) in $B$ were pooled, solubilized with detergent, and immunoprecipitated (IP) with KIF1B $\alpha$ antibody (1183) or guinea pig IgG ( $G p \operatorname{Ig} G$, control). The immunoprecipitates were analyzed by immunoblotting with antibodies against KIF1B $\alpha$, PSD-95, SAP97, S-SCAM, synaptotagmin (Syntag), and GRIP. KIF1B $\alpha$ coimmunoprecipitates with PSD-95, SAP97, and S-SCAM but not with synaptotagmin and GRIP. Input: $5 \%$.

proteins as motor receptors may have the following advantages. First, PDZ proteins in general contain, in addition to the PDZ domain, various domains for protein interactions, enabling motors to interact with a large number of proteins. Second, PDZ proteins may help the cargo-PDZ protein-motor complex dock at its destinations. For instance, PSD-95 may dock at the synapse by interacting with cytoskeleton-associated or cell-adhesion proteins including cysteine-rich interactor of PDZ3 (Niethammer et al., 1998) and neuroligin (Irie et al., 1997). Third, PDZ interactions may provide sites for modulation, because PDZ interactions are often regulated by phosphorylation (Sheng and Sala, 2001).

Second, our results suggest that $\mathrm{KIF} 1 \mathrm{~B} \alpha$ transports a large number of PSD-95 or S-SCAM-associated membrane or signaling proteins, including the Kv1.4 potassium channel (Kim et al.,
1995), NR2 subunits of NMDA receptors (Kornau et al., 1995), and neuronal nitric oxide synthase (nNOS) (Brenman et al., 1996). In support of this, a number of EM studies have shown that NR1 and NR2 subunits of NMDA receptors and nNOS occur nonsynaptically in the cytoplasm of axons and dendritic shafts (Aoki et al., 1993, 1994). Accordingly, the NR2B subunit of the NMDA receptor associates with moving vesicles (Setou et al., 2000). The fact that NMDA receptors could be transported by two different motors, KIF17 (Setou et al., 2000) and KIF1B $\alpha$, suggests a redundancy mechanism for a physiologically important cargo. More importantly, our results demonstrated that $\mathrm{KIF} 1 \mathrm{~B} \alpha$, unlike the dendrite-specific KIF17, is widely distributed in both dendrites and axons along with SAP97 and S-SCAM, and biochemically associates with SAP97 and S-SCAM. These results strongly suggest that $\mathrm{KIF} 1 \mathrm{~B} \alpha$ plays an important role in the axonal transport of a variety of SAP97- and S-SCAM-associated cargos, such as Kv1.4.

Finally, our results suggest additional mechanisms for the pathophysiology of CMT2A. In a previous study, cultured $k$ if $1 B-/-$ neurons exhibiting reduced survival and differentiation were rescued only by $\operatorname{KIF} 1 \mathrm{~B} \beta$, but not $\operatorname{KIF} 1 \mathrm{~B} \alpha$, suggesting that $\mathrm{KIF} 1 \mathrm{~B} \beta$ plays a major role in cell survival in a cell-autonomous manner (Zhao et al., 2001). Zhao et al. (2001) used a KIF1B $\alpha$ that is tagged with enhanced green fluorescent protein (EGFP) at its $\mathrm{C}$-terminal end (KIF1B $\alpha$-EGFP) in their rescue experiments. There is a possibility, however, that the KIF1B $\alpha$-EGFP may not interact with PDZ domains, because the free C-terminal carboxylate group of PDZ-binding peptide in general plays a key role in binding to PDZ domains (Sheng and Sala, 2001). Blocking the free carboxylate group by the addition of an extra amino acid residue at the $\mathrm{C}$ terminus of the PDZ-binding peptide has been shown to eliminate PDZ interaction (Xia et al., 1999). Thus it remains to be determined whether $\operatorname{KIF} 1 B \alpha$, along with PSD-95 relatives and S-SCAM, is also associated with neuronal survival, differentiation, and CMT2A peripheral neuropathy in a cellautonomous manner.

\section{REFERENCES}

Aoki C, Fenstemaker S, Lubin M, Go CG (1993) Nitric oxide synthase in the visual cortex of monocular monkeys as revealed by light and electron microscopic immunocytochemistry. Brain Res 620:97-113.

Aoki C, Venkatesan C, Go CG, Mong JA, Dawson TM (1994) Cellular and subcellular localization of NMDA-R1 subunit immunoreactivity in the visual cortex of adult and neonatal rats. J Neurosci 14:5202-5222.

Aoki C, Miko I, Oviedo H, Mikeladze-Dvali T, Alexandre L, Sweeney N, Bredt DS (2001) Electron microscopic immunocytochemical detection of PSD-95, PSD-93, SAP-102, and SAP-97 at postsynaptic, presynaptic, and nonsynaptic sites of adult and neonatal rat visual cortex. Synapse 40:239-257.

Bloom GS (2001) The UNC-104/KIF1 family of kinesins. Curr Opin Cell Biol 13:36-40.

Brenman JE, Chao DS, Gee SH, McGee AW, Craven SE, Santillano DR, Wu Z, Huang F, Xia H, Peters MF, Froehner SC, Bredt DS (1996) Interaction of nitric oxide synthase with the postsynaptic density protein PSD-95 and $\alpha 1$-syntrophin mediated by PDZ domains. Cell $84: 757-767$

Choi J, Ko J, Park E, Lee JR, Yoon J, Lim S, Kim E (2002) Phosphorylation of stargazin by PKA regulates its interaction with PSD-95. J Biol Chem 277:12359-12363.

Conforti L, Buckmaster EA, Tarlton A, Brown MC, Lyon MF, Perry VH, Coleman MP (1999) The major brain isoform of kiflb lacks the putative mitochondria-binding domain. Mamm Genome 10:617-622.

Garner CC, Nash J, Huganir RL (2000) PDZ domains in synapse assembly and signalling. Trends Cell Biol 10:274-280.

Goldstein LSB, Yang Z (2000) Microtubule-based transport systems in neurons: the roles of kinesins and dyneins. Annu Rev Neurosci 23:39-72.

Gong TW, Winnicki RS, Kohrman DC, Lomax MI (1999) A novel mouse kinesin of the UNC-104/KIF1 subfamily encoded by the Kif1b gene. Gene 239:117-127.

Hirao K, Hata Y, Ide N, Takeuchi M, Irie M, Yao I, Deguchi M, Toyoda 
A, Sudhof TC, Takai Y (1998) A novel multiple PDZ domaincontaining molecule interacting with $N$-methyl-D-aspartate receptors and neuronal cell adhesion proteins. J Biol Chem 273:21105-21110.

Hunt CA, Schenker LJ, Kennedy MB (1996) PSD-95 is associated with the postsynaptic density and not with the presynaptic membrane at forebrain synapses. J Neurosci 16:1380-1388.

Irie M, Hata Y, Takeuchi M, Ichtchenko K, Toyoda A, Hirao K, Takai Y, Rosahl TW, Sudhof TC (1997) Binding of neuroligins to PSD-95. Science 277:1511-1515.

Kennedy MB (2000) Signal-processing machines at the postsynaptic density. Science 290:750-754.

Kim E, Sheng M (1996) Differential K+ channel clustering activity of PSD-95 and SAP97, two related membrane-associated putative guanylate kinases. Neuropharmacology 35:993-1000.

Kim E, Niethammer M, Rothschild A, Jan YN, Sheng M (1995) Clustering of Shaker-type $\mathrm{K}+$ channels by interaction with a family of membrane-associated guanylate kinases. Nature 378:85-88.

Kim E, Cho KO, Rothschild A, Sheng M (1996) Heteromultimerization and NMDA receptor-clustering activity of Chapsyn-110, a member of the PSD-95 family of proteins. Neuron 17:103-113.

Klopfenstein DR, Vale RD, Rogers SL (2000) Motor protein receptors: moonlighting on other jobs. Cell 103:537-540.

Kornau HC, Schenker LT, Kennedy MB, Seeburg PH (1995) Domain interaction between NMDA receptor subunits and the postsynaptic density protein PSD-95. Science 269:1737-1740.

Koulen P, Garner CC, Wassle H (1998a) Immunocytochemical localization of the synapse-associated protein SAP102 in the rat retina. J Comp Neurol 397:326-336.

Koulen P, Fletcher EL, Craven SE, Bredt DS, Wassle H (1998b) Immunocytochemical localization of the postsynaptic density protein PSD-95 in the mammalian retina. J Neurosci 18:10136-10149.

Miki H, Setou M, Kaneshiro K, Hirokawa N (2001) All kinesin superfamily protein, KIF, genes in mouse and human. Proc Natl Acad Sci USA 98:7004-7011.

Nangaku M, Sato-Yoshitake R, Okada Y, Noda Y, Takemura R, Yamazaki H, Hirokawa N (1994) KIF1B, a novel microtubule plus end-directed monomeric motor protein for transport of mitochondria. Cell 79:1209-1220.
Niethammer M, Valtschanoff JG, Kapoor TM, Allison DW, Weinberg TM, Craig AM, Sheng M (1998) CRIPT, a novel postsynaptic protein that binds to the third PDZ domain of PSD-95/SAP90. Neuron 20:693-707.

Sans N, Petralia RS, Wang YX, Blahos II J, Hell JW, Wenthold RJ (2000) A developmental change in NMDA receptor-associated proteins at hippocampal synapses. J Neurosci 20:1260-1271.

Sans N, Racca C, Petralia RS, Wang YX, McCallum J, Wenthold RJ (2001) Synapse-associated protein 97 selectively associates with a subset of AMPA receptors early in their biosynthetic pathway. J Neurosci 21:7506-7516.

Scannevin RH, Huganir RL (2000) Postsynaptic organization and regulation of excitatory synapses. Nat Rev Neurosci 1:133-141.

Setou M, Nakagawa T, Seog DH, Hirokawa N (2000) Kinesin superfamily motor protein KIF17 and mLin-10 in NMDA receptor-containing vesicle transport. Science 288:1796-1802.

Sheng M, Sala C (2001) PDZ domains and the organization of supramolecular complexes. Annu Rev Neurosci 24:1-29.

Tomita S, Nicoll RA, Bredt DS (2001) PDZ protein interactions regulating glutamate receptor function and plasticity. J Cell Biol 153:F19-F24.

Valtschanoff JG, Weinberg RJ (2001) Laminar organization of the NMDA receptor complex within the postsynaptic density. J Neurosci 21:1211-1217.

Valtschanoff JG, Burette A, Davare MA, Leonard AS, Hell JW, Weinberg RJ (2000) SAP97 concentrates at the postsynaptic density in cerebral cortex. Eur J Neurosci 12:3605-3614.

Wyszynski M, Kim E, Yang FC, Sheng M (1998) Biochemical and immunocytochemical characterization of GRIP, a putative AMPA receptor anchoring protein, in rat brain. Neuropharmacology 37:1335-1344.

Xia J, Zhang X, Staudinger J, Huganir RL (1999) Clustering of AMPA receptors by the synaptic PDZ domain-containing protein PICK1. Neuron 22:179-187.

Zhao C, Takita J, Tanaka Y, Setou M, Nakagawa T, Takeda S, Yang HW, Terada S, Nakata T, Takei Y, Saito M, Tsuji S, Hayashi Y, Hirokawa N (2001) Charcot-Marie-Tooth disease type 2A caused by mutation in a microtubule motor KIF1B $\beta$. Cell 105:587-597. 